\title{
Reproductive cycle of the broomtail wrasse, Cheilinus lunulatus inhabiting coral reef in Hurghada, Red Sea, Egypt.
}

\author{
Ahamad M. Azab ${ }^{1}$, Mostafa A. Mousa ${ }^{2}$, Hassan M. Khalaf-Allah ${ }^{1}$ and \\ Mosab A. M. Ali ${ }^{3}$ \\ 1- Marine Biology branch, Zoology Depart., Faculty of Science, Al-Azhar \\ University, Cairo, Egypt \\ 2- National institute of Oceanography and fisheries, Alexandria \\ 3- Marine Biology branch, Zoology Depart., Faculty of Science, Al-Azhar \\ University, Assiut branch.
}

\section{ABSTRACT}

The present study deals with demonstrate the reproductive cycle of the broomtail wrasse, Cheilinus lunulatus which monthly collected from coral reef in Abu Galawa lagoon, Hurghada, Red Sea, during the period from December 2011 to November 2012. Results showed that, the averages of male and female gonadosomatic indices (GSI) were gradually increased during spring and summer months. Irregular trend was recorded to the female hepatosomatic index during all months of the year. It may be due to partially spawning in this fish. Shape, weight, size, colour, texture and structure of gonads were changed with the change of maturity stages. The testicular activity can be classified into five stages: immature stage, stimulating spermatogenesis, rapid spermatogenesis, mature (ripe) testis and Spent testis. Seven stages were recognized during the ovarian activity (previtellogenesis, earlyvitellogenesis, mid-vitellogensis, late-vitellogenesis, pre-spawning, ripe and spent stages). The testicular and ovarian developments were initiated when the day length (photoperiod) and water temperature had begun to increase during March to April. During May to August, however, the gradual increase of both photoperiod and water temperature reached its maximum values, gonads had ensured completion of testicular and ovarian development. It was concluded that Cheilinus lunulatus in Abu-Galawa lagoon of Hurghada, partially spawned during a long spawning season, which extended from May to October. It synchronizes between both males and females with coordination to increasing of both photoperiod and water temperature.

Keywords: Reproductive cycle; coral reef fishes; broomtail wrasse; Cheilinus lunulatus; Hurghada.

\section{INTRODUCTION}

From the economic importance of view, the Red Sea coasts constitute a very important sector in the Egyptian fisheries, both for significant total catch and a large number of economically important species. Research on reef fisheries and fish biology has a short history. Concurrently, reef fish biology flourished with numerous academic studies of small elements of reef fish communities. Coral reefs of the Red Sea support approximately 400 fish species which utilize corals for shelter, food and/or breeding ground. However, a little is known about the biology of the large variety of fish living in and around the coral reefs in the Red Sea (ERSR, 1998 and Mohamed, 1999).

Al-Ghardaqa (Hurghada) has one of the Egyptian shores in the Red Sea. The shore is deserted with small local settlements. Near the shore, the sea bottom characterized by reefs, which emerge from the water or are submerged, allowing 
tranquil and complete observation of this extremely rich environment. The first few meters of the reef are the richest in life and colors, a megalopolis, where a large part of the fish and other animals are concentrated (Randall and Heemstra, 1991; Heemstra and Randall, 1993; Osman, 2000; Farghal, 2009; Hamed, 2009 and Abd El-Gaid, 2014).

Labridae is one of the most interesting and numerically abundant families of fish. It is very widely distributed in marine waters; mostly from the coast line to about $160 \mathrm{~m}$ depth on sandy bottom, shallow coral and rocky reefs. Most species of wrasse fish are carnivorous of benthic invertebrates or fish. Some species are planktivores, corallivores and cleaners that feed on the ectoparasites of other fish. The broomtail wrasse, Cheilinus lunulatus is a large wrasse with a restricted distribution in the Arabian Peninsula. It is found in the Red Sea, Horn of Africa and coasts of Yemen; inhabiting coral reefs and adjacent rubble of sand and sea grass habitats. The maximum age of this fish is 19 years with a rapid growth rate (in males $55 \mathrm{~cm}$ in TL), it has a primary and initial color phases. It feeds mainly on hard shelled invertebrates especially mollusks and echinoderms. This fish is protogynous and associated in colonies of 4-8 females with a single large male (FAO, 1983; Randall, 1983; Gomon and Randall, 1984; Lieske \& Myers, 1994; Allam et al., 2005 and Khalaf Allah, 2013).

Knowledges of the gonadal cycles and their functional mechanisms in fish have essential value for the successful management of either natural fisheries or fish farming. The histological structure and seasonal variations of the teleostean gonads have attracted the attention of many investigations notably by Argyris (2005); Marcano et al. (2007); Ramirez et al. (2008); Mousa (2010); Khallaf et al. (2012); Konan et al. (2014) and Mohamed et al. (2014).

Few studies are available on the broomtail wrasse, C. lunulatus (Fisher, 1973; Randall, 1983; Lieske \& Myers, 1994 and Khalaf Allah, 2013). However, information on the reproductive cycle of the broomtail wrasse, C. lunulatus is lacking. Therefore, the principal objective of the present work is to provide biological informations on reproductive cycle of the broomtail wrasse, $C$. lunulatus, inhabiting coral reef in Hurghada, Red Sea, Egypt.

\section{MATERIAL AND METHODS}

\section{Study area:}

Abu Galawa lagoon is a small lagoon lies near Abu Galawa reef which situated about $7 \mathrm{~km}$ NE the Marine Biological Station in Hurghada, Red Sea. The maximum water depth ranged between $15-20 \mathrm{~m}$ during high tide period. It is situated between latitude $27^{\circ} 18^{\prime} 43.3^{\prime \prime} \mathrm{N}$ and longitude $33^{\circ} 48^{\prime} 4.7^{\prime \prime} \mathrm{E}$. The shape of the lagoon is generally rectangular with front-reef developed in irregular prongs in the east side. The bottom topography is flat consisting from many faces such as biogenic sand, algae, seagrass bed and coral reefs. Some sand mounds among the seagrass carpet are observed and inhabited by suspension feeding burrowing crustacean, some economic fish and few species of shells. The northern and southern sides are clearly biogenic sand, the middle part of Abu Galawa lagoon represented by seagrass carpet about $1000 \mathrm{~m}^{2}$. The western side opened to big lagoon relatively deep than this lagoon. The maximum coral development in the eastern side is covered by dense coral reef and the maximum depth in this area about 15 meters (Fig. 1). 


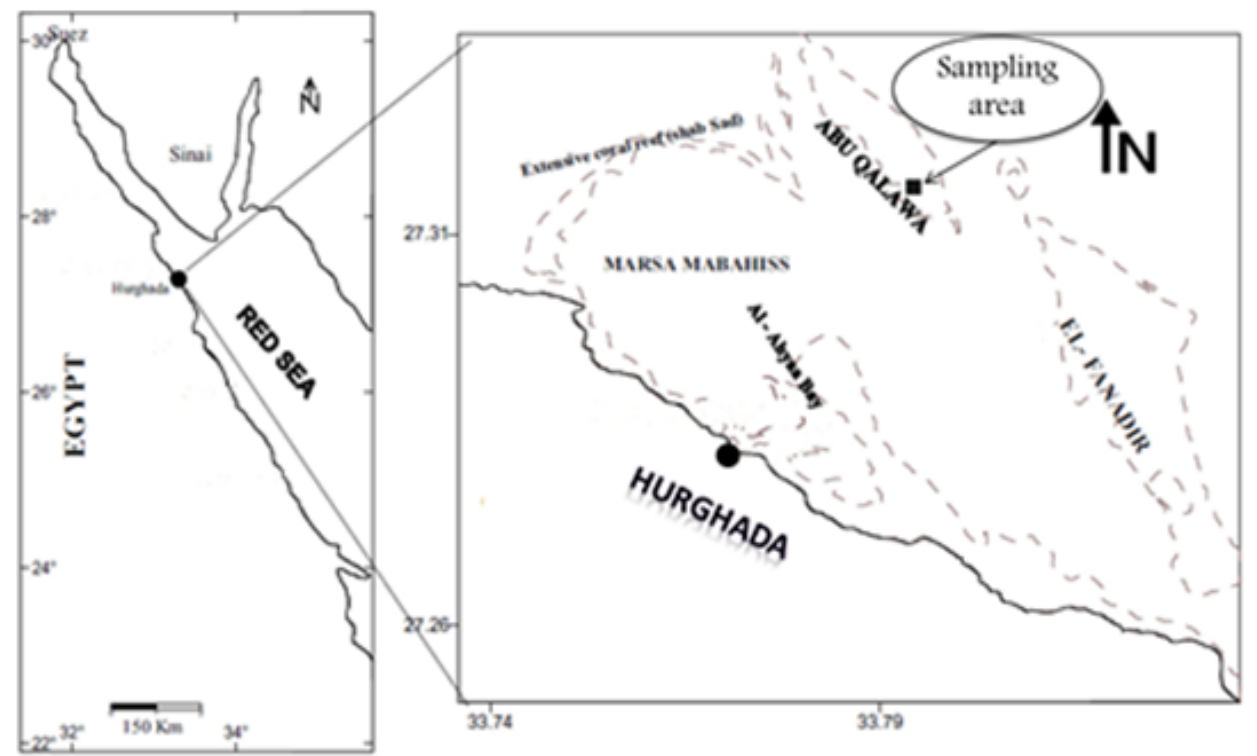

Fig. 1: Map of the Red Sea showing the sampling area.

\section{Environmental factors:}

Surface water temperature $\left({ }^{\circ} \mathrm{C}\right)$ was recorded after measuring it by using hydro lab system, Hanna Instrument, Model: HI 9828. Day length (photoperiod) was calculated by the "Authority of Meteorology".

\section{Specimens collection:}

A total of 107 specimens of broomtail wrasse, Cheilinus lunulatus formed the materials for the present study. Fish specimens were monthly collected from Abu Galawa lagoon in Hurghada, Red Sea, during the period from December 2011 to November 2012. Long lines net were the main fishing method used to collect the fish. Wherever possible fish were examined fresh or preserved in $10 \%$ formalin solution for latter examination. In the laboratory, fish were identified; total and standard lengths were measured to the nearest millimeter and recorded. Fish were also weighted to the nearest 0.1 gram and then the following studies were carried out.

\section{Reproduction:}

\section{Gonado-somatic and hepato-somatic indices:}

To study gonado-somatic index and hepato-somatic index, fish were wet weighted in grams and their standard lengths were measured to the nearest millimeter and recorded. Gonads and liver were removed and wet weighted to the nearest 0.01 gm. Gonado-somatic index (G.S.I.) and hepato-somatic indexes (H.S.I.) were calculated for each maturity stages according to the (Sokal and Rohlf, 1969) as in the following equations:

$$
\begin{gathered}
\text { G.S.I. }=\frac{\text { wet weight of gonad }(\mathrm{gm})}{\text { wet weight of fish }(\mathrm{gm})} \times 100 \\
\text { H.S.I. }=\frac{\text { wet weight of liver }(\mathrm{gm})}{\text { wet weight of fish }(\mathrm{gm})} \times 100
\end{gathered}
$$

\section{Maturity stages:}

From the intact gonads, the maturity stages were assessed first according to Mousa (1994). The assessments were based on the bases of seasonal changes in the histomorphology and gonado-somatic index. The monthly percentage of each maturity stages in males and females were calculated and recorded. 


\section{Oocyte diameter:}

Oocytes were preserved immediately in saline solution, placed on a glass slide and measured with an ocular micrometer. The diameters of the oocytes were determined by taking the mean of the maximum and minimum diameter of only those oocytes, which had been sectioned through the nucleus. The mean diameters of the oocytes and nuclei were determined by measuring 15 oocytes in each examined ovary.

\section{Gonad histology:}

After examination of the gonad condition, gonads were cut into small pieces ( 5 $\mathrm{mm}$ thick) and preserved immediately in Bouin's fluid for at least 72 hours, dehydrated in ethyl alcohol, cleared in xylene, embedded in paraplast wax (M.P. 58 ${ }^{\circ} \mathrm{C}$ ), sectioned at the thickness of 4-6 microns and stained with Harris`s haematoxylin and eosin solution. Finally, the slides were microscopically examined, then photographed and described.

\section{RESULTS}

\section{Environmental factors:}

The maximum average value of surface water temperature was recorded during July $\left(33.46^{\circ} \mathrm{C}\right)$ and the minimum was $20.84^{\circ} \mathrm{C}$ during January. The highest value of photoperiod was recorded during August $\left(13,51^{\prime}\right)$ and the lowest was 10 , 27 during December (Table 1).

Table 1: Monthly variations of environmental factors in the water of the Red Sea, Hurgada during the year, 2011- 2012.

\begin{tabular}{|l|l|l|}
\hline \multirow{2}{*}{ Months } & \multicolumn{2}{|l|}{ Environmental factors } \\
\cline { 2 - 3 } & Temperature $\left({ }^{\circ} \mathrm{C}\right)$ & Photoperiod $(\mathrm{h})$ \\
\hline January & 20.84 & $10,36^{`}$ \\
\hline February & 21.18 & $11,12^{`}$ \\
\hline March & 24.57 & $12.00^{`}$ \\
\hline April & 24.59 & $12,48^{`}$ \\
\hline May & 27.14 & $13,30^{`}$ \\
\hline June & 29.69 & $13,51^{`}$ \\
\hline July & 33.46 & $13,41^{`}$ \\
\hline August & 31.97 & $13,06^{`}$ \\
\hline September & 30.48 & $12,19^{`}$ \\
\hline October & 27.82 & $11,32^{`}$ \\
\hline November & 25.17 & $10,49^{`}$ \\
\hline December & 21.4 & $10,27^{`}$ \\
\hline
\end{tabular}

\section{Gonado-somatic index and hepato-somatic index:}

The averages of male and female gonado-somatic indices (GSI) were very low in December, being 0.06 and 0.26 respectively. They gradually increased during spring and summer months. The male GSI reached the highest value $(0.32)$ during September; female reached its highest value (2.54) during July. Then, the average of GSI of each decreased during October and November (Table 2 and Fig. 2).

The average of male hepato-somatic index slightly increased during April (1.15). The highest values of male hepato-somatic index were recorded during October (1.19) and November (1.23) respectively. Iirregular trend was recorded to the female hepatosomatic index during all months of the year (Table, 2 and Fig. 2). 
Table 2: Monthly variations in gonado-somatic index (G S I) and hepato-somatic index (H S I) of $C$. lunulatus, collected from Red Sea, Hurghada, during the period from December 2011 to November 2012.

\begin{tabular}{|c|c|c|c|c|c|c|}
\hline \multirow{3}{*}{ Months } & \multicolumn{3}{|c|}{ Males } & \multicolumn{3}{|l|}{ Females } \\
\hline & \multirow{2}{*}{$\begin{array}{l}\text { Fish } \\
\text { No. }\end{array}$} & \multicolumn{2}{|l|}{ Mean \pm S.D } & \multirow{2}{*}{ Fish No. } & \multicolumn{2}{|l|}{ Mean \pm S.D } \\
\hline & & G S I & H S I & & G S I & H S I \\
\hline December & $\varepsilon$ & $0.06 \pm 0.021$ & $0.91 \pm 0.104$ & $\varepsilon$ & $0.12 \pm 0.03$ & $0.83 \pm 0.387$ \\
\hline January & $r$ & $0.10 \pm 0.07$ & $0.92 \pm 0.120$ & 0 & $0.26 \pm 0.079$ & $1.22 \pm 0.268$ \\
\hline February & 2 & $0.07 \pm 0.007$ & $0.86 \pm 0.127$ & 6 & $0.35 \pm 0.075$ & $1.04 \pm 0.226$ \\
\hline March & 3 & $0.09 \pm 0.01$ & $0.77 \pm 0.107$ & 5 & $0.40 \pm 0.219$ & $0.80 \pm 0.170$ \\
\hline April & 3 & $0.13 \pm 0.00$ & $1.15 \pm 0.00$ & 6 & $0.55 \pm 0.202$ & $1.37 \pm 0.228$ \\
\hline May & 5 & $0.17 \pm 0.044$ & $0.04 \pm 0.363$ & 6 & $0.65 \pm 0.333$ & $0.81 \pm 0.210$ \\
\hline June & 5 & $0.15 \pm 0.00$ & $0.74 \pm 0.00$ & 11 & $0.99 \pm 0.595$ & $1.22 \pm 0.304$ \\
\hline July & 3 & $0.29 \pm 0.225$ & $0.90 \pm 0.783$ & 5 & $2.54 \pm 1.684$ & $1.47 \pm 0.321$ \\
\hline August & 3 & $0.243 \pm 0.165$ & $1.06 \pm 0.435$ & 5 & $0.82 \pm 0.482$ & $1.02 \pm 0.402$ \\
\hline September & 4 & $0.32 \pm 0.192$ & $0.70 \pm 0.228$ & 5 & $0.27 \pm 0.219$ & $1.05 \pm 0.099$ \\
\hline October & 3 & $0.23 \pm 0.185$ & $1.19 \pm 0.079$ & 3 & $0.33 \pm 0.215$ & $0.83 \pm 0.289$ \\
\hline November & 4 & $0.09 \pm 0.091$ & $1.23 \pm 0.314$ & 4 & $0.11 \pm 0.035$ & $1.02 \pm 0.167$ \\
\hline
\end{tabular}
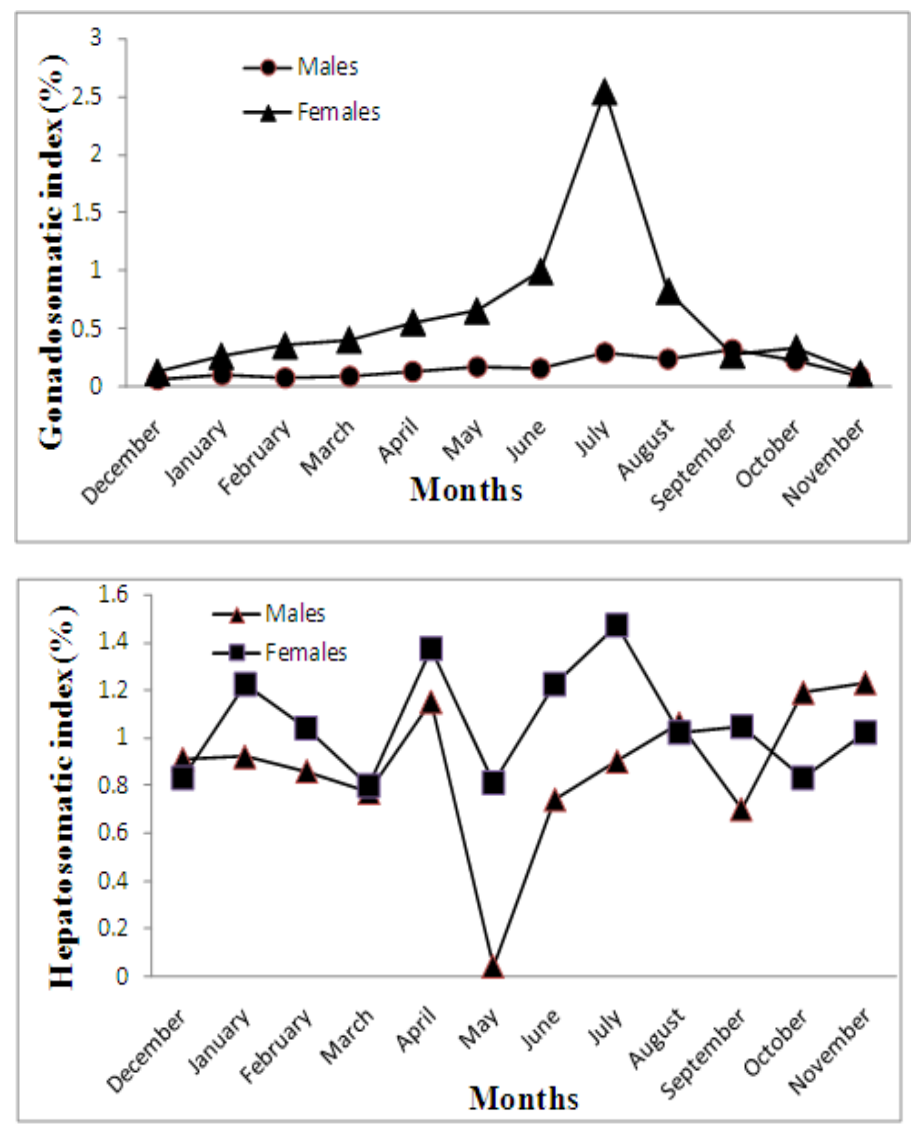

Fig. 2: Gonado-somatic index and hepato-somatic index of C. lunulatus, collected from Red Sea, Hurghada, at different months during the period of study.

\section{Gonad morphology:}

The testes of male broomtail wrasse, C. lunulatus, are elongated, opaque and have the genital blood vessel running along their inner side. The testicular lobes are generally, equal in size, but occasionally one is shorter than the other. They are known to remain separated from one another for almost their entire length. At the hind most part, however, lobes are attached together to form a common spermatic duct. They are exhibited a remarkable variations in shape, size, color and texture during the successive developmental stages (Plate, I A). 
The ovaries of female C. lunulatus (Plate, I B) are paired, elongated structures, lying in the posterior region of the abdominal cavity and being firmly attached to the dorsal peritoneum by the mesovarium. They are separated throughout most of their length but they unite posteriorly for a short distance to form oviduct that open at the tip of urinogenital papilla. The ovary of the fish is circular in cross section. The ovaries are known to exhibit remarkable variation in shape, colour; and texture during the successive developmental stages of fish. The size and weight of the ovaries are found to vary greatly according to the different stages of maturity. During the early growth phase of the fish, the ovaries appear as flaccid, delicate and translucent structures of dull pink colour. They become much distended and large in size during breeding period, when they take a tinge of yellow color they look like mulberry due to the presence of large ova inside them.

\section{Maturity stages:}

The testis of male $C$. lunulatus can be classified according to the morphological structure into five maturity stages. These stages are immature, premature, mature, ripe and spent (Plate, I C). The ovary of female C. lunulatus can be classified according to the morphological structure into seven maturity stages; these are immature, premature, mature, prespawning, ripe, spawning and post spawning or spent (Plate, I D).

\section{Testicular cycle of male $C$. Iunulatus:}

Histologically, the testis of $C$. lunulatus is approximately tongue shaped in transverse sections with an outer convex and inner concave side. Testis is composed of numerous seminiferous lobules, which are held together by inter-lobular septa, mainly of connective tissue. The lobules are varied in size, but a single layer of fusiform boundary cells with elongated nuclei bound of each. The sperm duct is situated in the dorsomedian side of the testis and runs throughout its length. A distinct testicular wall of a connective tissue thin membrane also envelops the whole testis (Plate, II A\&B). Data showed that, the testicular activity can be classified into the following five stages:

\section{Stage I: Immature}

The immature testes were filamentous in shape, thin, translucent, pale in colour and occupy a very small proportion of the belly cavity (Plate, I C). This stage was noticed to be concomitant with the lowest value of environmental factors (temperature and photoperiod). It extends all over the winter and beginning of spring with different frequencies overlapping with the other stages (Fig. 3). In this stage, the mean GSI was $0.06 \pm 0.018$ and HSI was $0.88 \pm 0.12$ (Tables, $3 \& 4$ ). The testis contains small sized lobules and a relatively large interlobular space filled with dense stroma of connective tissue and interstitial cells. The main components of the lobules are sperm mother cells and spermatogonia (Plate, II A\&B).

\section{Stage II: Stimulating spermatogenesis:}

During this stage, the premature testes became slightly enlarged, thin, flattened and semi-translucent (PLATE, I C). This stage extends from January to late June, being commenced with the gradual increase in both photoperiod and water temperature (Fig. 3). The GSI was: $0.31 \pm 0.41$ and HSI was: $0.96 \pm 0.26$ (Tables $3 \&$ 4). The spermatogenic activity was obviously in progress. The size of the lobules had noticeably exhibited a gradual increase, being accompanied by a marked reduction of the interlobular connective tissue. 


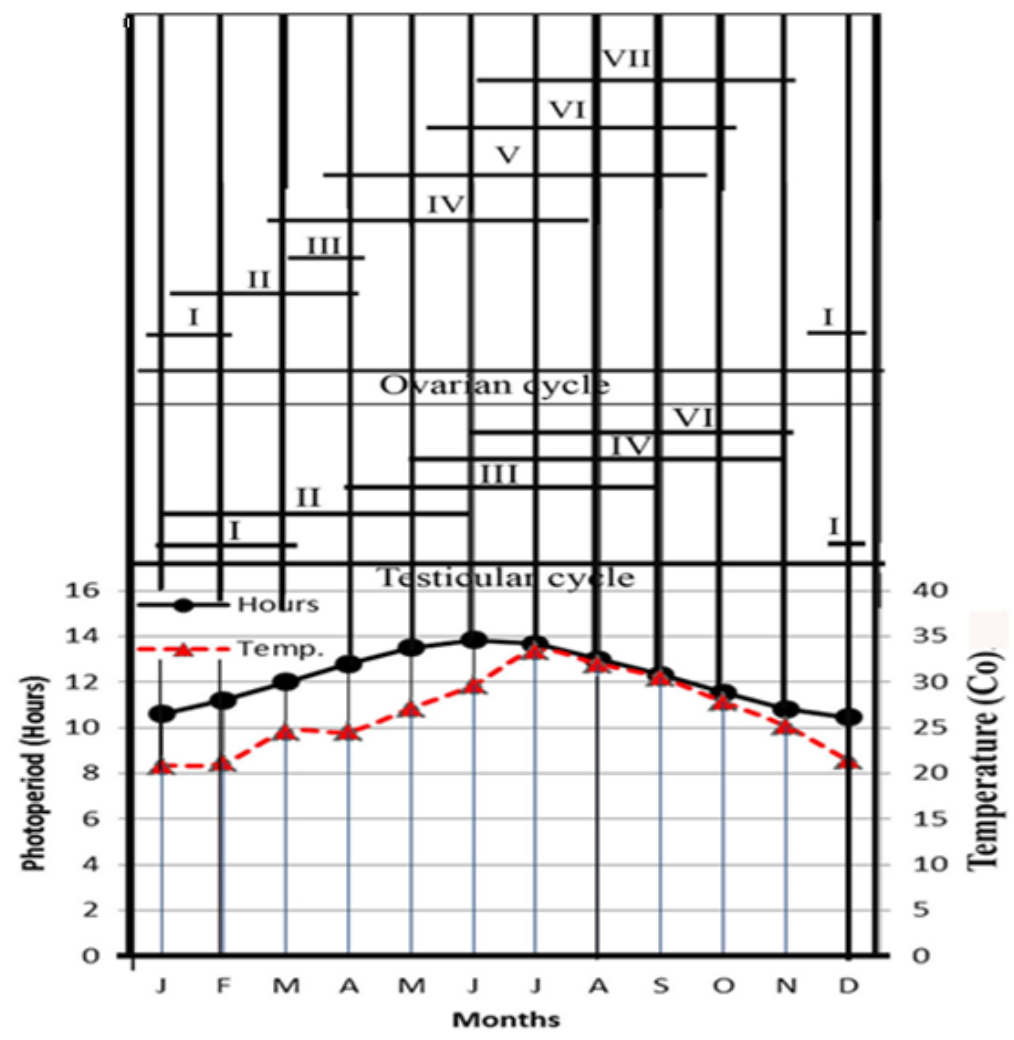

Fig. 3: Testicular and ovarian cycles of $C$. lunulatus collected from Red Sea in relation to the annual fluctuations of the day length (photoperiod) and water temperature.

Table 3: Variations in gonado-somatic index (G S I), hepato-somatic index (H S I) and oocyte diameter of C. lunulatus, at different maturity stages.

\begin{tabular}{|l|l|l|l|l|l|l|l|l|}
\hline \multirow{2}{*}{$\begin{array}{l}\text { Maturity } \\
\text { stages }\end{array}$} & Males & \multirow{2}{*}{ Fish No. } & \multicolumn{2}{l|}{ Mean \pm S.D } & \multicolumn{2}{l|}{ Females } \\
\cline { 3 - 9 } & & G S I & H S I & No. & Gean \pm S.D & \multicolumn{2}{l|}{ Oocyte diameter } \\
\hline I & 9 & $0.06 \pm 0.018$ & $0.88 \pm 0.12$ & 9 & $0.25 \pm 0.14$ & $1 \pm 0.19$ & $20-90$ & $54.6 \pm 22.39$ \\
\hline II & 7 & $0.31 \pm 0.41$ & $0.96 \pm 0.26$ & 9 & $0.31 \pm 0.13$ & $0.98 \pm 0.35$ & $100-130$ & $114.7 \pm 11.23$ \\
\hline III & 6 & $0.21 \pm 0.12$ & $0.87 \pm 0.47$ & 4 & $0.49 \pm 0.12$ & $1.32 \pm 0.34$ & $140-170$ & $156 \pm 11.81$ \\
\hline IV & 7 & $0.30 \pm 0.18$ & $0.78 \pm 0.41$ & 10 & $0.64 \pm 0.31$ & $1.14 \pm 0.28$ & $180-260$ & $213.8 \pm 24.99$ \\
\hline V & 6 & $0.14 \pm 0.16$ & $0.83 \pm 0.23$ & 16 & $1.04 \pm 0.92$ & $1.17 \pm 0.34$ & $195-360$ & $294 \pm 59.15$ \\
\hline VI & & & & 6 & $2 \pm 1.29$ & $1.17 \pm 0.21$ & $290-390$ & $332.5 \pm 32.5$ \\
\hline VII & & & & 6 & $0.12 \pm 0.04$ & $1.06 \pm 0.38$ & & \\
\hline
\end{tabular}

Table 4: Monthly variations in maturity stages of $C$. lunulatus, collected from Red Sea, Hurghada, during the period from December 2011 to November 2012.

\begin{tabular}{|c|c|c|c|c|c|c|c|c|c|c|c|c|c|c|}
\hline \multirow{3}{*}{ Months } & \multicolumn{6}{|c|}{ Males } & \multicolumn{8}{|c|}{ Females } \\
\hline & \multirow{2}{*}{$\begin{array}{l}\text { Fish } \\
\text { No. }\end{array}$} & \multicolumn{5}{|c|}{ Maturity stages } & \multirow{2}{*}{$\begin{array}{l}\text { Fish } \\
\text { No. }\end{array}$} & \multicolumn{7}{|c|}{ Maturity stages } \\
\hline & & $\mathrm{I}$ & II & III & IV & $\mathrm{V}$ & & $\mathrm{I}$ & II & III & IV & $\mathrm{V}$ & $\mathrm{VI}$ & VII \\
\hline December & 4 & 100 & - & - & - & - & 4 & 100 & - & - & - & - & - & - \\
\hline January & 3 & 66.6 & 33.3 & - & - & - & 5 & 80 & 20 & - & - & - & - & - \\
\hline February & 2 & 50 & 50 & - & - & - & 6 & 66.7 & 33.3 & - & - & - & - & - \\
\hline March & 3 & 33.3 & 66.7 & - & - & - & 5 & - & 40 & 40 & 20 & - & - & - \\
\hline April & 3 & - & 66.7 & 33.3 & - & - & 6 & - & 16.6 & 16.7 & 50 & 16.6 & - & - \\
\hline May & 5 & - & 40 & 40 & 20 & - & 6 & - & - & - & 16.7 & 66.6 & 16.6 & \\
\hline June & 5 & - & 20 & 50 & 20 & 20 & 11 & & - & - & 18.2 & 45.4 & 27.3 & 9.1 \\
\hline July & 3 & - & - & 33.3 & 33.3 & 33.4 & 5 & - & - & - & 20 & 40 & 20 & 20 \\
\hline August & 3 & - & - & 33.3 & 33.3 & 33.4 & 5 & - & - & - & 20 & 40 & 20 & 20 \\
\hline September & 4 & - & - & 25 & 50 & 25 & 5 & - & - & - & - & 20 & 40 & 40 \\
\hline October & 3 & - & - & - & 33.3 & 66.7 & 3 & - & - & - & - & 33.3 & 33.3 & 33.4 \\
\hline November & 4 & - & - & - & 25 & 75 & 4 & - & - & - & - & - & - & 100 \\
\hline
\end{tabular}


Moreover, most of the tesrticular lobules became filled with cysts of different stages of spermatogenesis. However, the predominance of spermatocytes and appearance of spermatids particularly characterized this stage. Small clusters of spermatozoa are seen. However, spermatogenesis does not appear to have taken place simulataneously in all the seminiferus lobules. The interstitial cells are comparatively abundant in the connective tissue matrix between the lobules. The lobule boundary cells are seen along the boundaries of the lobules (P Plate, II C).

\section{Stage III: Rapid spermatogenesis:}

In this stage, the mature testes lost their translucency and exhibited a pink colour, owing to their increased vascularity as they also manifested marked increases of both weight and volume (PLATE, I C). This stage extends from late April to September, when a gradual increase of both photoperiod and water temperature (Fig. 3). GSI was $0.21 \pm 0.12$ and HSI was $0.87 \pm 0.47$ (Tables $3 \& 4$ ). In this stage, the diameter of the seminiferous lobules increased and spermatogenic activity reaches its peak and the lobules became filled with cysts of all spermatogenic stages. They are separated from each other by a thin layer of interlobular connective tissue. Furthermore, this stage was characterized by the predominance of spermatids and spermatozoa (Plate, II D).

\section{Stage IV: Ripe testis}

The ripe testes appeared opaque, milky white, smooth and crumbled in texture. Milt could be easily extruded from the fish by gentle pressure on their bellies (Plate, I C). These testes were observed to have tremendously enlarged in size to the extent that they had almost filled the whole belly cavity. The ripening period was noticed to start concomitant with the increase of both the photoperiod and water temperatures, which extends from Mid-May to November (Fig. 3). GSI was $0.30 \pm 0.18$ and HIS was $0.78 \pm 0.41$ (Tables $3 \& 4$ ). The diameters of the testicular lobules attained their maximum width. The interlobular spaces appeared to be thicker than the previous ones. Testicular lobules were almost fully packed with mature spermatozoa. Active spermatogenic process is still visible in some lobules. Clusters of spermatids were observed at the margins of lobules. Spermatogonia and spermatocytes are completely absent (Plate, II E).

\section{Stage V: Spent testis}

The testes become thin, translucent and yellowish in colour. Their weights are relatively reduced (Plate, I C). This stage extends from late June to November, when the values of both photoperiod and water temperature are gradually decreased (Fig. 3). GSI was $0.14 \pm 0.16$ and HSI was $0.83 \pm 0.23$ (Tables $3 \& 4$ ). It was detected markedly by almost total cessation of spermatogenic activity and an increase in the interlobular space of connective tissue. The testicular lobules are diminished in sizes and their walls became thick, due to the contraction of their contents. Residual sperms, not expelled during the spawning stage, were abundantly present in a few lobules (Plate, II F).

\section{Ovarian cycle in female $C$. lunulatus:}

In cross section, the ovary of $C$. lunulatus appeared circular in shape and limited by a distinct wall. The germ mother cells or oogonia are commonly found in groups or nests in the outer cortical regions of the ovary. These oogonia are essentially responsible for producing the successive developmental stages of the eggs or oocytes. However, the whole process is known collectively as oogenesis (Plate, III A).

Seven stages of the ovarian development were recognized on the basis of the morphological and histological appearance of the ovaries, frequency of occurrence as well as the duration of the different developmental stages of the oocytes and the 
corresponding values of the gonadosomatic index and hepatosomatic index (Tables 3 \& 4). These stages were noticed to include previtellogenesis, early-vitelloogenesis, mid-vitellogenesis, late-vitellogenesis, pre-spawning, spawning (ripe) and spent.

\section{Stage I: Previtellogenesis}

The ovary appeared small in size, translucent, slightly fleshy in colour and occupied a small area of the body cavity (Plate, I D). This stage was noticed to be concomitant with the lowest values of environmental factors (temperature and photoperiod), which extend from December to late February (Fig. 3). The mean GSI was $0.25 \pm 0.14$ and HSI was $1 \pm 0.19$ (Tables $3 \& 4$ ). The oocytes were apparently representing the primary oocyte stages (Plate III, A).

\section{Stage II: Early vitellogenesis}

The ovaries appeared increase in volume than the preceding stage, occupying nearly half of the body cavity and their colour was in transition from reddish to yellowish colour (Plate, I D). This stage extends from late January to late April (Fig. $3)$. GSI was $0.31 \pm 0.13$ and HSI was $0.98 \pm 0.35$. The diameter of the oocytes in the ovaries ranged from 100 to $130 \mu \mathrm{m}$. (Tables $3 \& 4$ ). This stage marks the beginning of yolk deposition which was characterized by the appearance of minute spherical yolk granules (protied yolk) in the outer layer of the cytoplasm of the bitinctorial oocytes; being synchronized with the prevalence of a ring of oil droplets around the nucleus. Most of the oocytes in the early vitellogenic ovary are considered to represent the vesicles or primary yolk stages, owing to the presence of small cytoplasmic vesicles (Plate, III B).

\section{Stage III: Mid- vitellogenesis}

The ovaries acquired a yellowish colour and occupying more than half of the body cavity (Plate, I D). This stage extends from March to April; when photoperiod and water temperature are gradually increase (Fig. 3). GSI was $0.49 \pm 0.12$ and HSI was $1.32 \pm 0.34$. Oocyte diameter varied from 140 to $170 \mu \mathrm{m}$ (Tables $3 \& 4$ ). Most of the oocytes were seen in the primary yolk stages (Plate, III C).

\section{Stage IV: Late- vitellogenesis}

The ovaries occupied nearly the entire length of the body cavity. They exhibited a yellowish colour with more or less turgid structure (Plate, I D). This stage extends from late March to early August. During this period, photoperiod and water temperatures are gradually increased (Fig. 3). GSI was $0.64 \pm 0.31$ and HSI was $1.14 \pm 0.28$. Oocyte diameter ranged from 180 and $260 \mu \mathrm{m}$ (Tables $3 \& 4$ ). The oocytes were apparently belonging to the secondary yolk stage (Plate, III D).

\section{Stage V: Pre- spawning}

The ovaries were fully distended, occupying nearly the entire body cavity and exhibiting a translucent golden appearance (Plate, I D). This stage extends from midApril to October. This stage accompanied with the successive fall for both photoperiod and water temperatures (Fig. 3). The mean of GSI was $1.04 \pm 0.92$ and HSI was $1.17 \pm 0.34$. Oocyte diameter ranged between 195 and $360 \mu \mathrm{m}$ (Tables $3 \& 4$ ). Most of the oocytes belonged to the tertiary yolk stage (Plate, III, E).

\section{Stage VI: Spawning (Ripe)}

The ovaries were completely fully distended. They occupy all the body cavity and exhibited clear golden appearance (PLATE, I D). This stage extends from late May to early October and accompanied with the successive maximum values of photoperiod and water temperatures (Fig. 3). The mean GSI was $2 \pm 1.29$ and HSI was $1.17 \pm 0.21$. Oocyte diameter ranged between 290 and $390 \mu \mathrm{m}$ (Tables $3 \& 4$ ). Most of the ripe oocytes are mainly belonged to the tertiary yolk stage (Plate, III F). 


\section{Stage VII: Post-spawning (Spent):}

The ovaries were small in size, reddish in colour and flaccid in appearance with a thickned ovarian wall (Plate, I D). This stage extends from June to early November, before the decline of both photoperiod and water temperature to the minimum values (Fig. 3). The mean GSI was $0.12 \pm 0.04$ and HSI was $1.06 \pm 0.38$ (Tables $3 \& 4$ ). A great number of deformed oocytes and remains of empty follicles can be observed.

\section{DISCUSSION}

In the present study the monthly changes in the maturity stages and gonadosomatic index (GSI) for males and females indicated that, the spawning period occurred between May to October. This agrees with most summer spawning fish recorded by Shenouda et al. (1995) on Clarias lazera; Allam (1996) on Trachinotus ovatus; Jenny et al. (2007) on Brotula clarkae; Khalaf Allah (2009) on Terapon puta \& Lithognathus mormyrus and Mohamed et al. (2014) on Euthynnus alletteratus.

In the present study, the testes are made up of a plentiful numbers of seminiferous lobules. The latter's are bound together by means of a thin connective tissue. Both interstitial (leydig cells) and sertoli cells are present in the testes of the fish examined. Sertoli cells often occur in close proximity to the developing germ cells. The interstitial cells are distributed around the sperm duct as well as in between the testicular lobules. They attain their maximum development during ripeness and before spermiation. The signs of maximal activity of the interstitial cells were manifested by the remarkable increase of their number (hyperplasia) and of their size (hypertrophy). The present study indicated that, the interstitial cells are homologous with mammalian leydig cells and are the major site of androgen synthesis. Similar observations were detected by many investigators notably Yoneda et al. (1998), Mousa and Mousa (1999), Kokokiris et al. (2000), Khalil (2001), Albattal (2002), ElGreisy (2005 a \& b), Marcano et al. (2007) and Khalaf Allah (2009).

Seasonal variations in shape, volume and weight of the testes and ovaries of $C$. lunulatus are obviously correlated with the degree of the fish maturity. Gonadosomatic index (GSI) was increases gradually accompanying the maturation of gonads. Similar observations were reported by Mousa and Mousa (1999a), Kokokiris et al. (2000), Loir et al. (2001), Albattal (2002) Moharram (2003), El-Agamy et al. (2004), El-Greisy (2005 a \& b), Marcano et al. (2007) and Khalaf Allah (2009).

Junk (1999) concluded that spawning in fish can be affected by several different environmental factors; temperature and photoperiod influence fish reproduction by stimulating sensory organs that induce the production of gonad hormones, which can induce physiological or behavioral responses. The present study indicated that, such factors affect spermatogenesis, oogenesis, gonad maturation and spawning in $C$. lunulatus.

Environmental cues, such as photoperiod and temperature cycles, synchronize the internal timing system that controls breeding, control of final gamete maturation, ovulation and spawning. It has a very marked effect on the physiological and biochemical processes in fish, and a raised temperature regime has complex effects on fish reproductive, nerve and endocrine systems (Pankhurst et al., 1996; Luksiene and Svedang, 1997; Bromage et al., 2001; Kirschbaum and Schugardt, 2002; Rad et al., 2006; Wilkinson et al., 2010; Oliveira et al., 2011). Additional factors such as food availability and salinity of the water may play certain critical roles in the timing of teleost reproduction (Micale et al., 1987; Khalil, 2001 and Khalaf Allah (2009). 
Seven successive stages of ovarian development (previtellogenic, earlyvitellogenic, mid-vitellogenic, late-vitellogenic, pre-spawning or ripe, spawning and post-spawning) were observed in the ovaries of these fish. These findings are similar to those reported by Greeley et al. (1987); Mousa (1994); Merson et al. (2000); Khalil (2001); Albattal (2002) and Khalaf Allah (2009).

The first stage (previtellogenesis) is characterized by the presence of previtellogenic oocytes less than the minimum vitellogenic size of $30-40 \mu \mathrm{m}$ in diameter. It is not dependent upon the environmental factors (temperature and photoperiod). Therefore, it had extended throughout the whole year with different frequencies overlapping with the other stages.

The vitellogenesis (yolk deposition) occurred at the ovarian stage II (earlyvitellogensis) and vitellogenic stages III, IV and V (mid-; late-vitellogenesis; prespawning) are commenced concomitant with the gradual increase of both photoperiod and water temperatures. It is generally accepted that photoperiod and temperature are the two major environmental factors that mediate reproductive activities in fish. Similar observations were recorded by Lam (1983); Johnston et al. (1987); Albattal (2002) and Khalaf Allah (2009).

In the pre-spawning stage, most of the oocytes belonged to the tertiary yolk stage. The oil droplets coalescence and become less in number, i. e. the presence of some droplets of fat inside the mature oocytes. Pajuelo et al. (2008) mentioned that, the presence of a large droplet of fat inside the mature oocytes indicates the pelagic character of its spawning.

The ovarian stage VI (spawning or ripe stage) was observed during the maximum values of both photoperiod and water temperatures. The spawning females are characterized by the presence of ripe oocytes. As the spawning occurs during the reaching of photoperiod and water temperatures to its maximum values, the ovarian stage VII (post-spawning) extends from late June to early November. Similar observations were detected by Albattal (2002) and Khalaf Allah (2009).

From the present study, it was clear that, Cheilinus lunulatus exhibited one spawning season in a year. Maturity peak extended from May to October. The population of $C$. lunulatus in Abu-Galawa lagoon at Hurghada, starts spawning during the late of spring season and continue till the summer with synchronization between both males and females and increasing of both photoperiod and water temperature.

\section{REFERENCES}

Abd El-gaid, S.B. (2014). Biological studies on economicaly important bivalve species from Hurghada, Northern Red Sea Egypt. M.Sc. Thesis, Zool. Dept., Fac. Sci., AL-Azhar Univ., Pp: 179.

Albattal, A.A.E. (2002). Biological studies on the reproduction of Lates niloticus. M. Sc. Thesis, Zool. Dep., Fac. Sci., Al-Azhar Univ. Cairo., Pp: 294.

Allam, S.M. (1996). Reproductive biology of pelagic carangid fish, Trachinotus ovatus, from the Egyptian Mediterranean Sea. J. Egypt. Ger. Soc. Zool., 19 (B): $45-57$.

Allam, S.M.; Abu-Shabana, M.B. and Gamee, F. M. (2005). Age and growth of two most common species of wrasses: symphodus (crenilabrus) tinca and Xyrichthys novacula in Abu-Qir Bay, Alexandria, Egypt. Egypt. J. Aquat. Biol. \& Fish., 9 (4): 333-352. 
Argyris, K. (2005). Age, growth, mortality, reproduction and feeding habits of the striped sea bream, Lithognathus mormyrus (Pisces: sparidae), in the coastal waters of the Thracian Sea, Greece. Scientia Marina., 69(3): 391- 404.

Bromage, N.R.; Porter, M. and Randall, C.F. (2001). The environmental regulation of maturation in farmed finfish with special reference to the role of photoperiod and melatonin. Aquacult., 197: 63-98.

El-Agamy, A.; Zaki, M.I.; Awad, G.S. and Negm, R.K. (2004). Reproductive biology of Boops boops (family Sparidae) in the Mediterranean environment. Egypt. J. Aquat. Res., 30 (B): $241-254$.

El-Greisy, Z.A.E. (2005a). Reproductive biology and histology of male brushtooth lizard fish, Saurida undosquamis (Richadson), Family: Synodotidae, from the Mediterranean coast of Egypt. Egypt. J. Aqua. Res., 31 (1): 356-366.

El-Greisy, Z.A.E. (2005b). Reproductive biology and histology of female brushtooth lizard fish, Saurida undosquamis (Richadson), Family: Synodontidae, from the Mediterranean coast of Egypt. Egypt J. Aqua. Res., 31 (1): 367 - 386.

ERSR (1998). Red Sea coastal and marine protected area strategy Egyptian Red Sea coastal marine resource management project funded by the Global environment facility/World Bank Red Sea Governorate, ARE, Report, (Part 2), pp.1-5.

FAO (1983). FAO species identification sheets (Labridae), Fishing area, 51 (W. Indian Ocean). National Museum of Victoria, Melbourne, Victoria, Australia, pp. $1-11$.

Farghal, T.K. (2009). Studies on the impact of human activities on the structure and population of the coral reef fish families at Hurgada. M.Sc. Thesis, Zool. Dept, Fac. Sci., AL-Azhar Univ., Pp: 233.

Fisher, W. (1973). FAO Species Identification Sheets for Fishery Purposes. Mediterranean and Black Sea (fishing area 37). Fisher, W. (ed.)., Rome, FAO, Vol. 1:

Gomon, M.F. and Randall, J.E. (1984). Labridae. In: FAO Species Identification Sheets for Fishery Purposes. Fischer, W. and Bianchi, G. (eds.)., FAO species identification sheets for fishery purposes. Western Indian Ocean fishing area 51: Vol. 2.

Greeley, M. S. Jr.; Calder, D. R. and Wallace, R.A. (1987). Oocyte growth and development in the striped mullet, Mugil cephalus, during seasonal ovarian recrudescence: relationship to fecundity and size at maturity. Fish Bull., 85: $187-200$.

Hamed, S.A. (2009). Biological and ecological studies on some oyester species from the coast of the Egyption Red Sea. M. Sc. Thesis, Zool. Dept., Fac. Sci., ALAzhar Univ. pp.: 260.

Heemstra, P.C. and Randall, J.E. (1993). FAO Species Catalogue, Groupers of the World (Family Serranidae, Subfamily Epine; helinae). An annotated and illustrated catalogue of the grouper, rockcod, hind, coral grouper and lyretail species known to date. FAO Fishers synopsis. Rome, FAO., 125 (16):pp.: 383.

Jenny, A.; Wilberto, A.; Manuel, R. and Luis, Z. (2007). Reproduction of the fish, Brotula clarkae (Pisces: Ophidiidae) in the Colombian Pacific. Revista de Biologia Tropical, 55 (3-4): 957 - 967.

Johnston, C.E.; Gray, R.W.; McLennan, A. and Peterson, A. (1987). Effects of photoperiod, temperature, and diet on the reconditioning response, blood chemistry and gonad maturation of Atlantic salmon kelts (Salmo salar) held in fresh water. Can. J. Fish. Aquat. Sci., 44: 702 - 711. 
Junk, W.J. (1999). The flood pulse concept of large rivers: learning from the tropics. Large Rivers 11(3): 261 - 280.

Khalaf-Allah, H. M. M. (2009). Biological studies on some Mediterranean Sea fish species with special reference to their feeding habits, growth and reproduction. Ph.D. Thesis, Zool. Dep. Fac. Sci., Al-Azhar Univ., Egypt., Pp: 432.

Khalaf-Allah, H.M.M. (2013). Morphological adaptations of digestive tract according to food and feeding habits of the broomtail wrasse, Cheilinus lunulatus. Egypt. J. Aquat. Biol. Fish., 17 (1): 123-141.

Khalil, N.A.M. (2001). Biological studies on the reproduction of Liza ramada in Egypt. Ph.D. Thesis, Zool., Dep. Fac. Sci., Ain Shams Univ., Pp: 257.

Khallaf, E. A.; Mohammad M. and Authman, N. (2012). Interaction of the mormyrid fish Mormyrus kannume (Forsskål, 1775) reproduction and feeding intensity with the environment in a Nile Delta Canal, Egypt. Egypt. J. Aquat. Biol. Fish., 16 (1):73 - 94.

Kirschbaum, F. and Schugardt, C. (2002). Reproductive strategies and developmental aspects in mormyrid and gymnotiform fish. J. Physiol. Paris, 96: 557 - 566.

Kokokiris, L.; Mourot, B.; Le Menn, F.; Kentouri, M. and Fostied, A. (2000). Endocrine changes during the annual reproductive cycle of the red porgy, Pagrus pagrus (Teleostei, Sparidae). Fish physiol. Bioch., 23(1): $1-11$.

Konan, Y.A; Koné, T; Bamba, M. and Koné, I. (2014). Reproductive strategies of the catfish, Clarias buettikoferi (Pisces, Clariidae) in the Tanoe-Ehy Swamp Forest (South-Eastern Côte d'Ivoire). World J. Fish and Mar. Sci. 6 (1): 16-23.

Lam, T. J. (1983). Environmental influences on gonadal activity in fish. In: Fish Physiology. Hoar, W.S.; Randall, D.J. and Donaldson, E.M. (eds.)., Academic Press New York, NY and London., IXB: $65-116$.

Lieske, E. and Myers, R. (1994). Collins Pocket Guide, Coral Reef Fish. Indo-Pacific \& Caribbean including the Red Sea. Haper Collins Publishers, pp.: 400.

Loir, M.; Le Gac, F.; Somarakis, S. and Pavlidis, M. (2001). Sexual and gonadal cycle of the common dentex, Dentex dentex, in intensive culture. Aquacul., 194 (34): $363-381$.

Luksiene, D. and Svedang, H. (1997). A review on fish reproduction with special reference to temperature anomalies. Fiskeriverket, Kustlaboratoriet, Gamla Slipvägen 19, 74071 Oregrund, pp.: 35.

Marcano, D.; Cardillo, E.; Rodriguez, C.; Poleo, G.; Gago, N. and Guerrero, H.Y. (2007). Seasonal reproductive biology of two species of freshwater cat fish from the Venezuelan Xoodplains. General and comparative Endocrinol., 153: $371-377$.

Merson, R. R..; Casey, C. and Martinez, B. (2000). Oocyte development in summer flounder: seasonal changes and steroid correlates. J. Fish Biol., 57(1): 182196.

Micale, V.; Perdichizzi, F. And Santangelo, G. (1987). The gonadal cycle of captive white bream, Diplodus sargus (L.). J. Fish Biol., 31: 435 - 440.

Mohamed, A.S. (1999). Population dynamics and stock assessment of some species of genus Cephalopholis and genus Variola from the Red Sea Egypt. M.Sc.Thesis, Zool. Dept., Fac. Sci., Assiut Univ., pp.: 149.

Mohamed, H.; El-Haweet, A. and Sabry, E. (2014). Reproductive biology of little tunny, Euthynnus alletteratus (Rafinesque, 1810) in the Eastern Coast of Alexandria, Egypt. Egypt. J. Aquat. Biol. \& Fish., 18 (1): 139-150. 
Moharram, S.G. (2003). Reproductive biology of Uranoscopus scaber (Linnaeus, 1758) Family: Uranoscopidae in the Egyptian Mediterranean waters. Egypt. J. Aquat. Biol. Fish., 7 (2): 175 - 208.

Mousa, M.A. (1994). Biological studies on the reproduction of mullet, Mugil cephalus (L.) in Egypt. Ph. D. Thesis, Zool. Dept., Fac. Sci., Ain Shams Univ., Pp: 278.

Mousa, M.A. (2010). Induced spawning and embryonic development of Liza ramada reared in freshwater ponds. Animal Reprod. Sci, 119:115 -122.

Mousa, M.A. and Mousa, S.A. (1999). Immunocytochemical study on the localization and distribution of the somatolactin cells in the pituitary gland and the brain of Oreochromis niloticus (Teleosti, Cichlidae). General and comparative Endocrinol., 113: 197 - 211.

Oliveira, C.; Mañanós, E.; Ramos, J. and Sánchez-Vázquez, F.J. (2011). Impact of photoperiod manipulation on day/night changes in melatonin, sex steroids and vitellogenin plasma levels and spawning rhythms in Senegal sole, Solea senegalensis. Comp. Biochem. Physiol., 159: 291-295.

Osman, A.G.M. (2000). Taxonomical and biological studies on some species of Genus Epinephelus (Family: Serranidae) from the Red Sea. M. Sc. Thesis, Fac. Sci., Al-Azhar Univ., Egypt, pp: 221.

Pajuelo, J.G.; Gonzalez, J.A.; Santana, J.I.; Lorenzo, J.M.; Mederos, A.G. and Tuset, V. (2008). Biological parameters of the bathyal fish black scabbardfish, Aphanopus carbo (Lowe, 1839) off the Canary Islands, Central-east Atlantic. Fish. Res., 92: 140-147.

Pankhurst, N.W.; Purser, G.J.; Van Der Kraak, G.; Thomas, P.M. and Forteath, G.N.R. (1996). Effect of holding temperature on ovulation, egg fertility, plasma levels of reproductive hormones and in vitro ovarian steroidogenesis in the rainbow trout, Oncorhynchus mykiss. Aquacult., 146: 277- 290.

Rad, F.; Bozaoğlu, S.; Gözükara, S.E.; Karahan, A. and Kurt, G. (2006). Effects of different long-day photoperiods on somatic growth and gonadal development in Nile tilapia (Oreochromis niloticus L.). Aquacult., 255: 292-300.

Ramirez, L.G.; Ramirez, S.R.; Vazquez, J.A.R. and Sanson, G.G. (2008). Reproduction of the fish, Gymnothorax equatorialis (Pisces: Muraenidae) in Jalisco and Colima, Mexico. Revista de Biologia Tropical, 56 (1): 153 - 163.

Randall, J.E. (1983). Red Sea Reef Fish. Randall, J.E. (ed.)., Immel publishing limited. London WIX5AE, pp.: 192.

Randall, J.E. and Heemstra, P. C. (1991). Revision of Indo-Pacific groupers (Perciformes: Serranidae: Epinephelinae), with descriptions of five new species. Indo-Pacific Fish, 20: 1 - 296.

Shenouda, T.S.; Massoud, A.A. and Mahfouz, M.E. (1995). Spawning indices and fecundity of Clarias lazera (Cuv.\& Val.) in Rosseta branch of the River Nile. J. Egypt. Ger. Soc. Zool., 17 (B): 65 - 92.

Sokal, R.R. and Rohlf, F. J. (1969). Biometry. Freeman and Company (ed.)., San Francisco, Ca, Pp: 776.

Wilkinson, R.J.; Longland, R.; Woolcott, H. and Porter, M.J.R. (2010). Effect of elevated winter-spring water temperature on sexual maturation in photoperiod manipulated stocks of rainbow trout (Oncorhynchus mykiss). Aquacult., 309: $236-244$.

Yoneda, M.; Tokimura, M.; Fujita, H.; Takeshita, N.; Takeshita, K.; Matsuyama, M. and Matsuura, S. (1998). Reproductive cycle and sexual maturity of the anglerfish, Lophiomus setigerus in the East China Sea with a note on specialized spermatogenesis. J. Fish Biol., 53 (I): 164 - 178. 


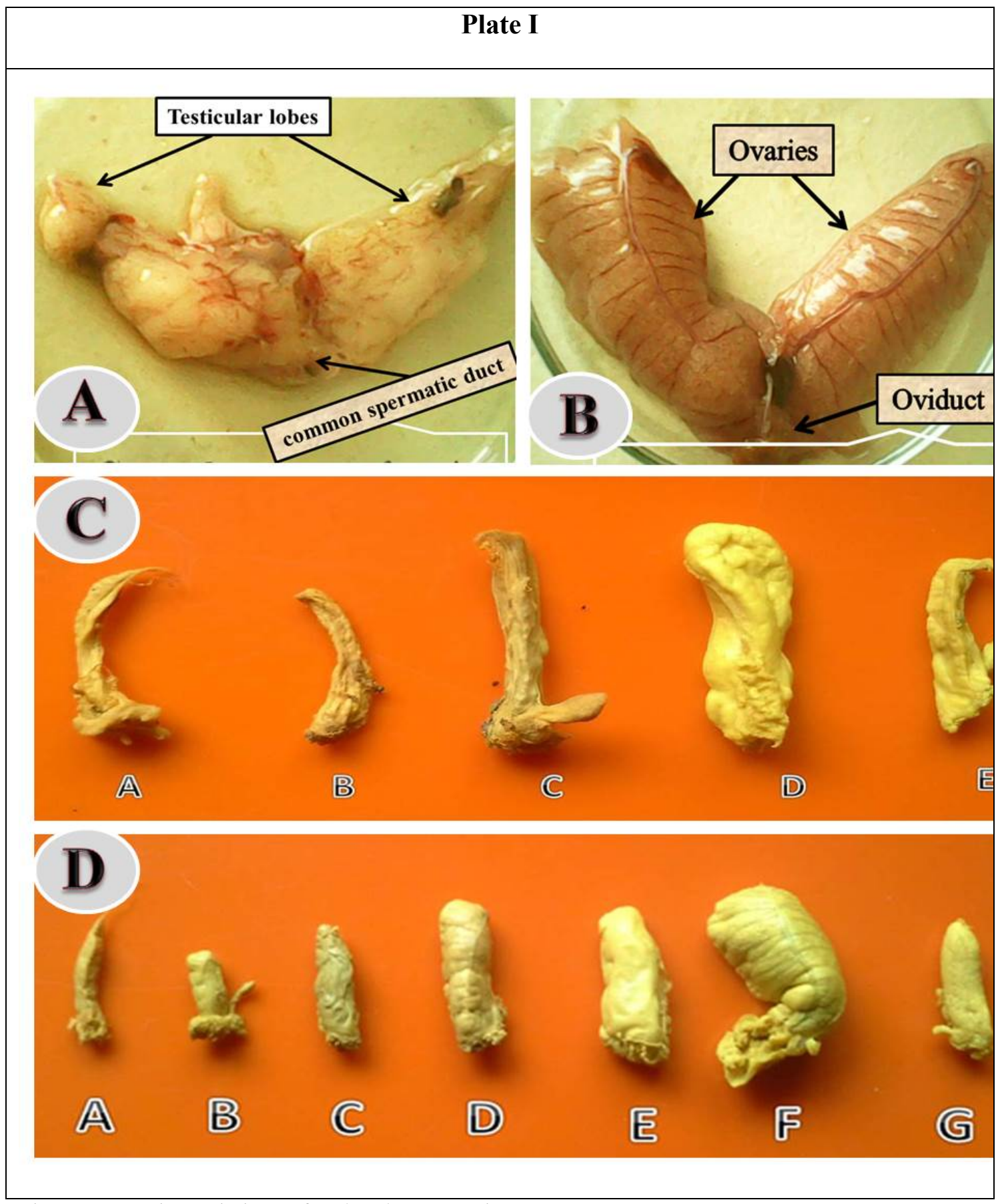

Plate I: General morphology of C. lunulatus gonads.

A: General structure male testis

B: General structure female ovary

C: Male maturity stages; A- Immature, B- Premature, C-Mature, D-Ripe and E-Spent.

D: Female maturity stages; A- Immature, B- Premature, C-Mature, D- prespowning, E-Ripe, FSpawning and G- Spent. 


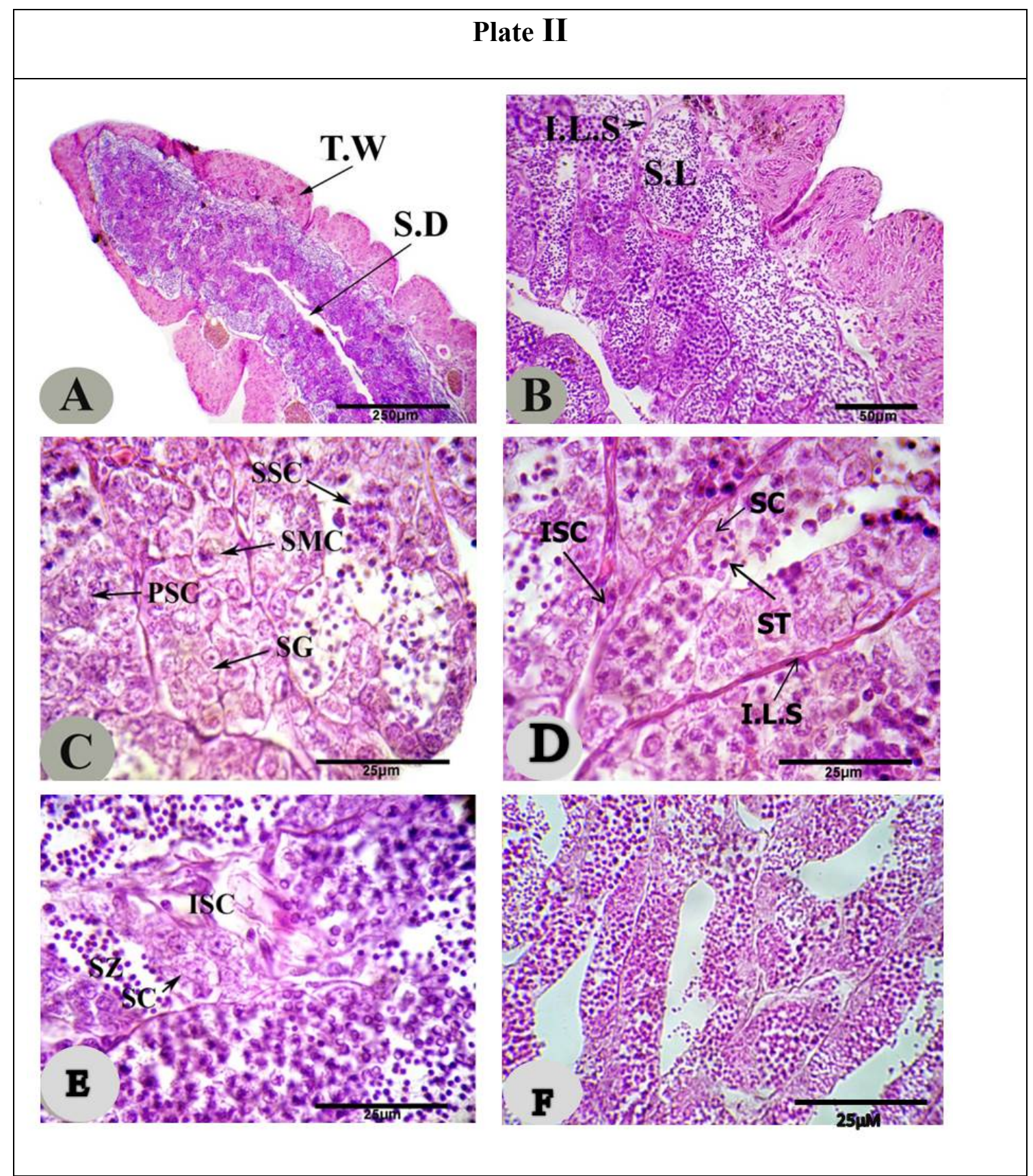

Plate II: Photomicrographs of histological sections in testis of male C. lunulatus:

(A): T.S. in immature testis, showing the testicular wall (TW), spermatic duct (SD).

(B): Enlarged portion of previous T.S., displaying interlobular septum (ILS) between seminiferous lobules.

(C): T.S. in stimulating spermatogeneic testis, showing sperm mother cells (SMC), spermatogonia (SG), primary spermatocytes (PSC) and secondary spermatocytes (SSC).

(D): T.S. in rapid stimulating spermatogenic testis, showing primary spermatocytes (PSC), secondary spermatocytes (SSC), spermatids (ST), interstitial cells (ISC), Sertoli cells (SC).

(E): T.S. in ripe testis, showing Interstitial cells (ISC), Sertoli cells (SC) and spermatozoa (SZ).

(F): T.S. in spent testis showing empty spaces inside seminiferous lobules. 


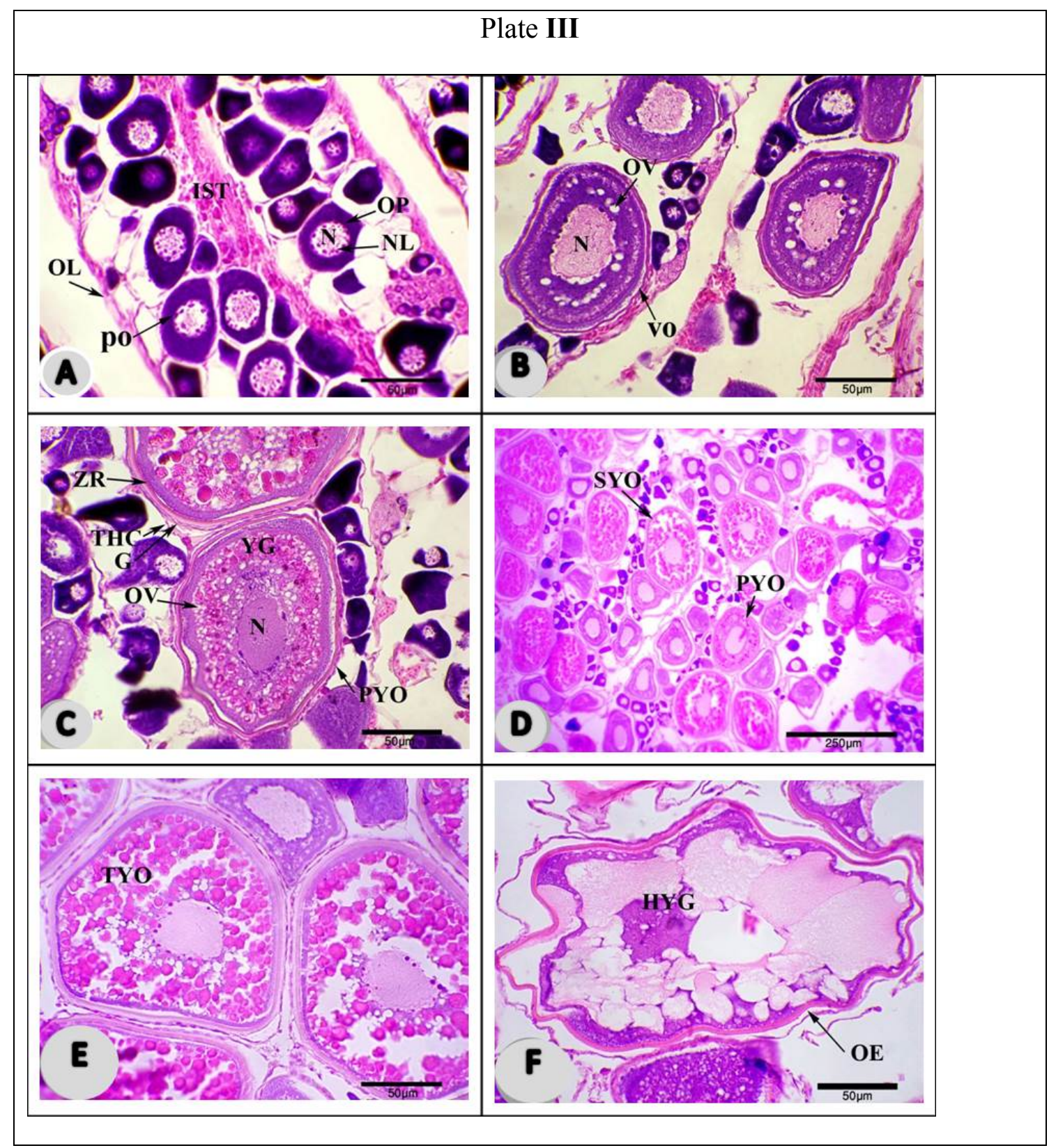

Plate III: Photomicrographs of histological sections in ovaries of female C. lunulatus:

(A): T.S. in pre-vitellogenic stage showing ovarian wall (OW), primary oocyte (PO) and the ovigerous lamellae (OL).

(B): T.S. in early-vitellogenic stage, showing vesicle oocyte (VO), including oil vesicles (OV) and large nucleus $(\mathrm{N})$.

(C): T.S. in mid-vitellogenic stage, showing oil vesicles (OV), yolk globules (YG) and large nucleus (N) in the primary yolk oocyte (PYO) and thick wall; theca layer (TH), granulosa (G) and zona radiata $(\mathrm{ZR})$.

(D): T.S. in late-vitellogenic stage, showing the secondary yolk oocyte (SYO) and primary yolk oocyte (PYO).

(E): T.S. in pre-spawning stage, showing the tertiary yolk oocyte (TYO).

(F): T.S. in spawning ovary, showing homogenized yolk globules (HYG) in ovulated eggs. 


\section{ARABIC SUMMARY}

الدورة التناسليه لأسماك الملاص القاطنة للشعاب المرجانية بالغردقة ـ البحر الأحمر - مصر

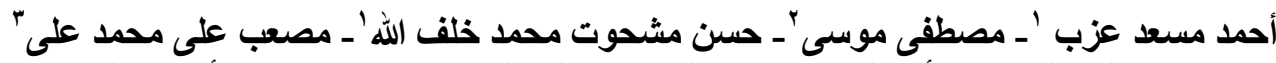

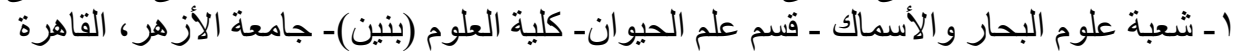

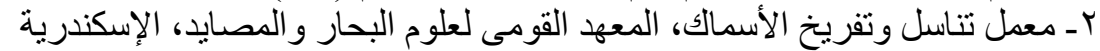

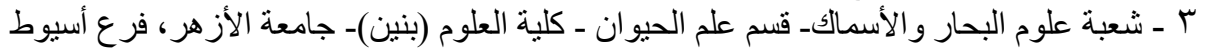

تعتبر بيئة الثعاب المرجانية فى الساحل المصرى للبحر الأحمر موطن بيئي مناسب لتربية العديد من اللماني

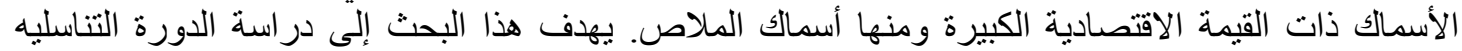

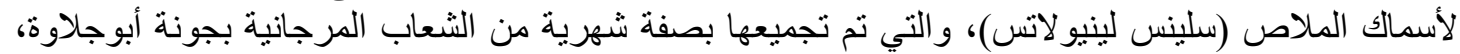

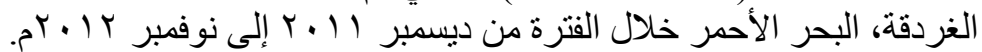

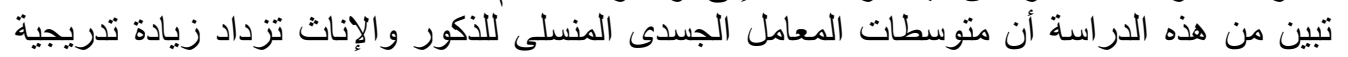

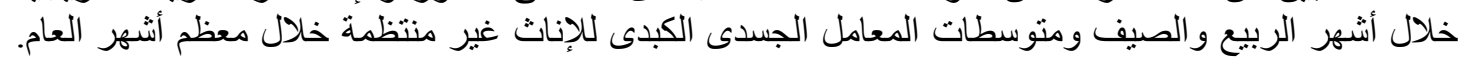

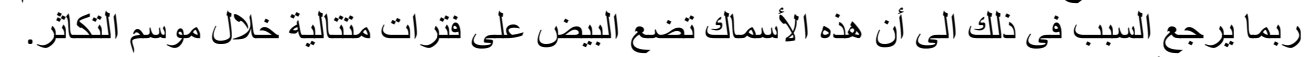

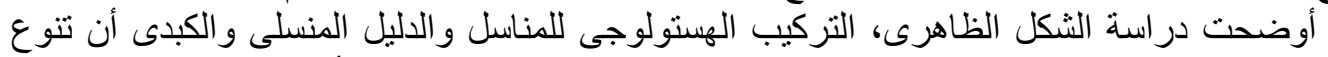

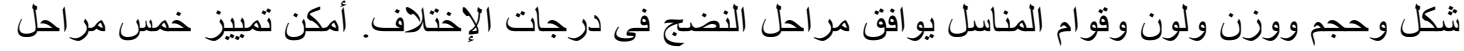

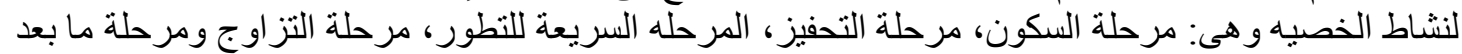

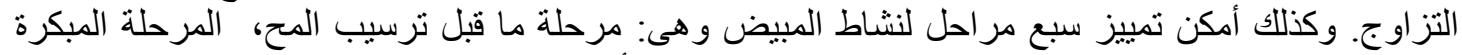

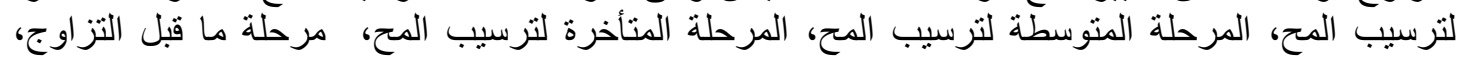

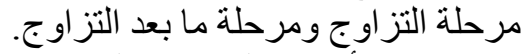

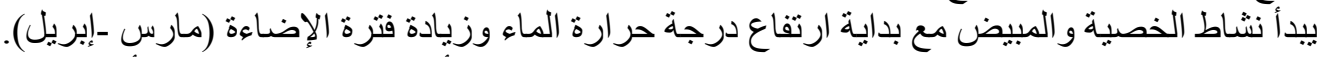

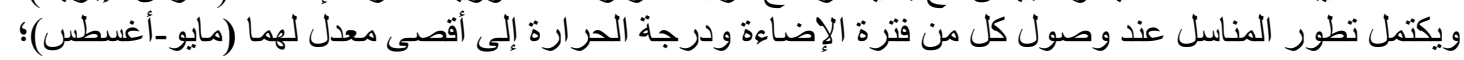

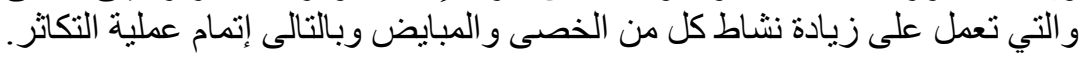

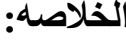

أن اسماك الملاص تقوم بعملية التكاثر مره و احده فى العام والتي تبلغ زروتها خلال التها الفتره من مايو الي

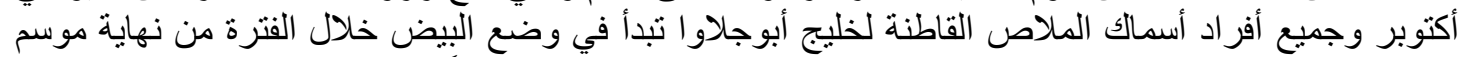

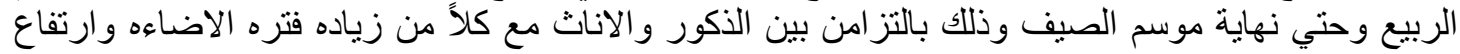

